DMYTRO HONCHARENKO,

Borys Grinchenko Kyiv University (Kyiv, Ukraine)

e-mail:d.goncharenko86@gmail.com,ORCID 0000-0002-2597-9740

\title{
DOES THE SOCIAL TEACHING OF THE CATHOLIC CHURCH CONTAIN THE MODERNIZED ELEMENTS OF THE MEDIEVAL DOCTRINA DE DUO GLADI?
}

The purpose of the medieval Catholic political and theological doctrine of the "two swords" was to ground the thesis of the supremacy of the pope's authority over political power, and this enabled the spiritual institute to claim on the issues of secular and state character. However, as a result of reform processes in Europe, the doctrine of the "two swords" has been minimized but it assumes that certain elements of the doctrine could be preserved till our time and used by the Church in a time-adapted form. The solution of this problem is based on the study of the social doctrines of the Roman Catholic Church, as far as it is the Catholic social doctrine that has absorbed a number of secular issues, and this enables the Church to influence on civil society by addressing problems in the economic, political and social realms. As the Doctrine of the Two Swords contained a political component, the main focus of the article is made on the study of the theoretical and practical steps of the Roman Catholic Church in the diplomatic and geopolitical arena which in some ways may be consistent with the provisions of medieval doctrine. However, by paying attention to the socio-political aspects, the Church reserves the right to exercise moral and ethical control over both society and government, thereby demonstrating that the spiritual institute obtains an important role in shaping the architecture of the modern world. Therefore, the purpose of the article is to investigate Catholic social doctrine and to identify its elements that can be interpreted as a modern realization of the medieval "two swords" theory.

Keywords: Catholic Church; Doctrine; "two swords"; Diplomacy; Catholic Social Doctrine; Pontiff; Geopolitics; State; Politics.

Introduction

The Medieval political and theological doctrine of the Catholic Church about "two swords" (doctrina de duo gladi) was aimed at the Catholic Church theses establishing, regarding to the supremacy of a pope over the secular monarchs, and securing the right of a spiritual institute to influence on the activity in the political sphere. The doctrines were based on the study of pope Gelasius I "about twosided power" and allegorical interpretation of Luka's Gospel (Lk. 22:36, 38) combined with Matthew's Gospel (Mt. 26: 52) provided by Bernardus Claraevallensis. According to Bernardus's interpretation "two swords" should point at two types of power: spiritual and secular respectively. All power was in the hands of Peter Apostol, consequently it was propriety of the Church, and only the Church gave on its own one sword to the secular power and another kept.

The Protestant Church subordinated to the state government as a result it was forced to abandon the theory after the Reformation in the 16th century. Having lost the political influence, the Church remained the right of moral and spiritual control under society; consequently it demonstrated that the spiritual institute obtained the crucial role in building the architecture of modern civil society which was the source of power in the democratic countries. Therefore, aspiration of the Catholic Church to influence on civil society through the system of social, economic and political doctrines could be viewed as so-called modernization of the medieval political and theological theory of "two swords".
The issue has not been considered in that light in foreign and national scientific environment. Particular elements encouraged the solution of the issue could be found in the papers of Russian scientist G. Sardarian. For instance, in the paper "Liberal Turn of the Catholic Social Doctrine at the period of Leo's XIII Pontificate" where the author stated that social doctrine of the pope Leo XIII paved the way for the further liberalization of the Catholic social doctrine and accelerated the Church's activity in the European and global democratic processes. Another paper of G. Sardarian "Political doctrine of Pope John XXIII" discovers a position of Pope John XXIII concerning political regimes, forms of governance and power implementation mechanisms. The metropolitan T. Kondrusiewicz in the paper "Church and State according to the Catholic Doctrine" examines the Catholic social doctrine for interrelations and co-existence of a state and spiritual institute. The vast information collection about political and social doctrines of the Church can be found in the encyclicals of Leo XIII "Rerum Novarum (1891)"; John the XXIII "Ad Petri Cathedram" (1959), "Mater et Magistra" (1961), "Gaudium et spes" (1965); John Paul II "Sollicitudo Rei Socialis" (1987); Benedict XVI "Caritas In Veritate" (2009).

The aim of the paper is to highlight the modern realization of the medieval "two swords" theory in the Catholic social doctrine. The following objectives should be considered to solve the stated problem:

- To investigate the social doctrines of the Catholic Church;

- To identify the concepts oriented on the solution of 
political and geopolitical problems in the official encyclicals;

- To reveal the analogy between the modern social and political doctrine of the Catholic Church and medieval "two swords" doctrine.

\section{Methods}

The methods of analysis and synthesis are used for highlighting the political issues in the social doctrines of the Catholic Church; the method of deduction is applied for the logical conclusion about the separate elements of the medieval "two swords" doctrine existence. The comparative method is implemented for correlation between political issues of the modern Catholic doctrine and the items of medieval "two swords" doctrine.

\section{Results and Discussions}

Having lost an opportunity to influence on the political and state processes, the Catholic Church concentrated on the problems of civil society as a prompt reaction on the social requests from "the grassroots" provided chances to spread the traditional for the Church principles of good and justice as well as it strengthened the authority and influence of the spiritual institute. The Church "had gradually considered itself as a free association of believers who were intended to spread the word of God through sermon and social doctrine" (Kanevskyi, 2003). The Church's mission to influence on society and its structures via social doctrine, responsibilities and tasks generated by the doctrine were mentioned in "Compendium of the Social Doctrine of the Church" (Compendium of the Social Doctrine of the Church, 2008).

The social doctrine of the Catholic Church had formed from the whole period of its historical existence; nevertheless, it had obtained the official embodiment from the moment of the encyclical authorized by the pope Leo XIII "Rerum Novarum" ("Of New Things") published in 1891. Except purely social issues, "Of New Things" has evoked the economic directed problems; some of them can be interpreted as a projection of the state policy program. Particularly the Catholic Church warns the state institutions to establish the national economy on the bases of socialism as it has a threat to private property, violates a right of the legal owner and leads to a conflict between the owners and laborers (Leo XIII, 1891: 4). Having implemented an idea about importance of the private property institute to the public and defended it from the social system attacks, the Catholic Church supported the capitalist model of household and secured free entrepreneurship development that became a base of the Eastern European market economy. Hence the Church had actually influenced on the direction of economic development in a number of Catholic countries via the social doctrine. Another aspect described in "Of New Things" was a warning for the states to avoid the attempts of nationalization of the private property objects as it contradicted the liberal and economic household models and prevented a consistent process of state's self-withdrawal from the economy regulation. Namely, due to the doctrine, the Church endeavored to define the border lines of state's authority - a state should not intervene: firstly, into a sphere of private property and, secondly, except abovementioned, into a citizen's private life. Simultaneously, a state should monitor the adherence to the social norms, rights, freedom and prevent any individual attempt to undermine "the mutual rights" (Leo XIII, 1891: 14). Relying on the abovementioned, a parallel can be drawn with the medieval "two swords" conception; in this case the Catholic Church poses a vector for the state institutions as in the middle Ages. Only under such conditions the focuses have shifted from the policy to economy and social aspects. The Church retains the right to define the borders within which the authorities can act regarding the citizens in the spheres of private property and life, to impose restrictions of authorities on the social processes. Moreover, the doctrine of the pope Leo XIII established the foundations for the further liberal ideology development which was an integral attribute of democratic values that had eventually formed the base for the political regimes of Western countries. The moment was mentioned in the article "Liberal Turn of the Catholic Social Doctrine at the period of Leo's XIII Pontificate" by G. Sardarian. The scientist noted that the tough doctrine's position of Leo XIII regarding to the acceptance of the indispensable human right to private property provided an opportunity for the further evolving of the Catholic social doctrine in "the direction of increasing liberalization", and the Church obtained the positions for the exceeding activity in the democratic processes in Europe and later around the world (Sardarian, 2016: 1436). Due to "Of New Things" the aim of a state is to secure social good for all segments of the population and protect society from the disruption, especially from the one that can appear on the ground of a conflict between hired employees and employers. The features of the medieval politic and theological "two swords" theory are followed here as the Catholic Church endeavors to influence on the sphere that is under the state's patronage and aims to be a mediator in the relations' regulation on the one hand and on the other hand - between a state and abovementioned segments, thereby occupies a leadership position in the social policy which according to the definition is one of the state's function. Consequently, we can cautiously note that the Church endeavors to act within the secular authority. While the social and economic issues were stressed in the doctrine "Rerum Novarum", the political issues depicted the internal situation in the Catholic countries as well as the international arena became the main theme in the encyclicals of the Catholic Church later. It could signify the willing of the Church to pose itself as a legitimate participant of the international political processes. For instance, John XXIII wrote in the first letter "Ad Petri Cathedram" ("To the Chair of Peter") (1959) about his intention to create global and universal Church that could take into account the political issues.

According to the context the Catholic Church had a message about the right solution of the state problems (considering the personal interests), namely, it was necessary for the international conferences to stress the need of searching and taking decisions that should be able to unite all humanity and demonstrate to the separate countries that "their right for freedom was secured". Thus, "John XXIII defined a shift away from opposition of the national state concept to the Church increase above a state and spiritual institute's intention to occupy a global position in values' promotion, namely democracy and human rights that were intrinsic for the Catholic Church" (Sardarian, 2017: 156). Based on the abovementioned we have come to a conclusion that a transformation of the Catholic Church social policy has occurred. The earlier social doctrines of the Catholic Church were limited to the property issues and laborers' vital activity, during the period of John XXIII pontificate a social conception of the Church had been transformed due to the international cooperation enhancement, economic, social and political systems' 
unification. The pope John XXIII renewed the approaches to the Catholic social doctrine and encouraged the Church "to be involved into the social problems' solution of all Christian community" in another encyclical "Mater et Magistra" "Mother and Teacher" (1961). The document raised a number of geopolitical themes: a problem of social inequality, the lack of equal distribution of good due to the imbalances in different economic sectors and agricultural potentials of the countries, a number of problems connected with the negative influence on the development of "third world countries" were defined (Yarotskyi, 2001: 57).

The offered position can be understood as the Church (as well as during the Middle Ages) closely monitors and reacts to the urgent global challenges that confront the Christian countries and has all the power to cope with them. Furthermore, paying attention to the global scale problems, the Catholic Church identifies its activity as unlimited to the borders and Catholic countries that gradually extends sphere of influence. The pope John XXIII succeeded to revise agenda and expand a sphere of attention of the Catholic Church through defining the Church's interests on a geopolitical level in the encyclical "Mother and Teacher". That had opened the new possibilities for a spiritual institute to influence on the geopolitical challenges in the sphere of state processes such as democracy and human rights. Hence, having considered the social course of the Catholic Church offered by the pope John XXIII, we are able to conclude that there has been a transformation and modernization of the some items from political and theological doctrine of "two swords", as a clear will of the Holy See to restore the leading positions in solving a number of social issues in the global scale and to obtain the priority under the global political connections among the Christian countries.

The attention of the Catholic Church to the political and social issues appeared in the doctrines as well as in the practical activity of the pontific John XXIII. For instance, during the Caribbean Crisis John XXIII addressed with the public call for resisting escalation and saving peace to the US President Kennedy and the USSR first secretary Khrushchev. The appeal of pontific was heard by the Soviet Union and Khrushchev personally sent a letter to the pope with a wish for health. Moscow attentively followed the geopolitical steps of the Catholic Church during the pontificate of John XXIII. After the speech of John XXIII with the appeal of saving peace during the Berlin Crisis of 1961, Moscow considered the pope's actions as a shift away from the US policy support and a decision about negotiation between Vatican and the USSR about normalization of bilateral relationships and their registration on a diplomatic level was approved, nevertheless the propositions were in a context of the large-scale religious persecutions in the USSR. The fact caused violent resistance of Vatican (Fylyppov, 2017: 103).

The pastoral constitution of the Latin Church "Gaudium et Spes" "Glad and Hope" (1965) was about the Church control under the authorities and their relations with society accepted at the Second Vatican Council. It should be mentioned that a thesis about autonomous existence of spiritual and political institute was written in the document, however, simultaneously it was specified that the autonomy was not directed on the mutual isolation of two institutes, in contrast, the aim of the autonomy was coordination of the cooperation. An interesting part highlighted in the pastoral constitution was in reserving a right to provide moral as well as political assessments of the statesmen.
Consequently, a spiritual institute is considered as an arbiter who has a right to reveal and highlight the state's miscalculations in social, economic or political sphere, or in other spheres of state's activity (Kondrusevych, 2005). A defined function of the Catholic Church about state's moral assessment was no other than mitigation and modernization of "two swords" conception, as the Catholic Church claimed its right to evaluate state's actions during the middle Ages.

The Catholic Church payed attention to the "internal" social problems, for instance: labor, relations between hired employees and employers, property issues, family problems, relations between society and power, etc. long before the works of the pope John XXIII and the Second Vatican Council. The spiritual activation in the political sphere began from the second half of the XX century. The Church started to apply to the adherents for the most urgent issues of external and internal policy and that moment was mentioned by T. Yevdokymova in the work: "Christian Social Doctrine: a Dialogue with the Modern Word" (Yevdokymova, 2000: 13).

The pontificate of the pope John Paul II had only strengthened positions of the Catholic Church on the international scene. The Holy See turned to the practical actions from the theoretical bases of the internal and external policy. It was stemmed from the fact of "cold war" escalation during the $80-\mathrm{s}$, the Catholic Church planned to enhance its international influence and authority trough the strengthening its positions in East European countries. John Paul II as an anticommunist perceived the countries as a base for the struggle against communist regime. The will and strategical aim of John Paul II also served the political interests of the USA, and a union with Reagan for realization of a mutually beneficial geopolitical target consisted in a struggle against the Eastern socialistic camp was attributed to him. Vatican's attention to the European policy became evident in the pope's support of Polish Oppositional Organization "Solidarity". Furthermore, a bank of Vatican provided financial assistance to the party, and in 2003 John Paul II openly encouraged the Polish to support Poland's accession to the EU (Ratnikov, 2014).

The role of Vatican in geopolitics noted the first president of USSR M. Gorbachev: "Nowadays we can say that everything happened in Eastern Europe would be impossible without pope's giant efforts and its role in policy and international scene" (Chetverykova, 2011: 86). Hence, in the context of the presented issue, the actions of the Roman Catholic Church at that period could be evaluated as a display, to the certain degree, of medieval political and theological conception of "two swords" which was realized according to the needs and demands of that time. The encyclical of John Paul II "Sollicitudo Rei Socialis" "On Social Concern" (1987) was about a confrontation between Western democracy and Eastern Marxist socialistic system. The Catholic social doctrine was aimed at confrontation revealing between two polar value systems and raising the problem of difference in individual and national development. Still there was a place for critic of a liberal model from Western capitalism as well as collective Marxist's system in the document. The encyclical stated that two offered systems were not flawless; simultaneously it was necessary to save human dignity within the systems and provided an opportunity for the Church to secure a place for pastoral activity as a spiritual institute's obligation of expanding religious activity in all spheres of human life (Holubev, 2012: 114).

The modernization of the medieval Catholic doctrine of 
"two swords" could be followed during the time of pontificate of Benedict XVI and Francis. The bright example of the Holy See diplomacy was a position on the international scene about a wish of European integration of Turkey. The common statement of the pope and patriarch Varfolomey was made in the context of the issue, where the heads of the Churches highlighted the necessity of respect the minority rights in the case of the EU enlargement that was interpreted as a critique of the Turkish authorities by the international community (Ratnikov, 2014).

Another example of the pope Benedict's XVI attention to geopolitics was a publication of his encyclical "Caritas In Veritate" "Charity in Truth" (2009). Having published just before the meeting of "The Group of Seven", a document raised merely political issues about the necessity of establishing the true "international political authorities" that would be recognized on the international level. The power should obtain the real credentials to secure safety and human rights at the global level, moreover it should have an opportunity of influence on the international community for legitimization of their decisions and those that were approved by the international forums.

The document offered to reform the UN and other international organizations for more efficient work in the issues of disarmament, migration policy, etc., inter alia (Chetverykova, 2011: 138).

The external political activity of the Catholic Church was also noticed during Francis's pontificate. His visit to Cuba in 2015 and negotiations with Raul and Fidel Castro could be interpreted as an international policy display of a spiritual institute that was in a certain sense the modernized element of the political conception of "two swords". In this case, according to the analytic of American fund "Heritage" Ganny Kintanos, a spiritual institute took the diplomatic functions and performed the role of mediator in the process of the normalization of relations between Washington and Havana (Aronov, Gostev, 2015).

\section{Conclusions}

The medieval Catholic doctrine of "two swords" came to an end due to the Reformation movements in Western Europe; nevertheless, having analyzed the social doctrines of the Roman Catholic Church we could cautiously admit that the particular elements of the doctrine were update and modernize according to the time challenges. For instance, the protection of capitalist economic system and private property, regulation of relations between state, hired employees and owners, etc. were emphasized in the social encyclicals of the pope Leo XIII. This is a signal that the Church is aimed at setting direction for the state institutes, as it can be found in the medieval "two swords" doctrine; however it is not performed via politics but through a social component that is defined as the state's prerogative. Notwithstanding the social doctrine of the pope Leo XIII was "internally" directed, the Roman Catholic Church had become to react on the world scale problems such as global social inequality, the lack of equal distribution of good due to the imbalances in different economic sectors and agricultural potentials of the countries, the problems that negatively influence on the "third countries" development had been considered and studied beginning with the works of the pope John XXIII and the Second Vatican Council. This gave an opportunity to a spiritual institute to expand its influence beyond the borders of Christian countries and took the initiative from the political institutes in the sphere of state formation processes such as democracy and human rights. The activity could be viewed as an attempt of the Holy See to return the primacy over the global political network among the Christian countries. A significant increase in the actions of a spiritual institute is in the political sphere. The Church has begun to address to their adherents from the most urgent issues of internal and external policy. The gradual shift from the theoretical works to practical diplomatic activity has been undertaken during the pontificates of John Paul II, Benedict XVI and Francis. As a result the modern realization of the particular elements from the medieval "two swords" doctrine can be traced through the social doctrines and diplomatic activity of the Catholic Church.

\section{REFERENCES}

Aronov, E. and Gostev, A. (2015). Big politics of the pope. Radio Freedom. Retrieved from https://www.svoboda.org/a/ 27261162.html (In Russian).

Chetverykova, O. N. (2011). Changes to the Vatican, or the Pope's Conspiracy against Christianity. Moscow: Eksmo (In Russian).

Compendium of the Social Doctrine of the Church (2008). Kyiv: Kairos (In Ukrainian).

Filippov, B. (2017). Cardinal Stefan Wyszyński - Initiator and Critic of Vatican's "Eastern Policy", 1945-1978. Hosudarstvo, relyhyia, tserkov v Rossii i za rubezhom, 35(1): 98-122. DOI: https:/ /doi.org/10.22394/2073-7203-2017-35-1-98-122 (In Russian).

Golubiev, K. (2012). The positioning of Catholic social doctrine in the encyclicals of Pope Ivan Paul II. Khristianskoe chtenie (Christian reading), 6: 95-130 (In Russian).

Kanevskyi, K. (2003). The Social Doctrine of the Catholic Church. "Rossyiskaia yustytsyia" (Russian justice). 4. Retrieved from https://www.sova-center.ru/religion/publications/2003/12/ d1475/?print=1 (In Russian).

Kondrusevych, T. (2005). Church and State in the Teachings of the Catholic Church. Svoboda sovesti v Rossii: istoricheskij $i$ sovremennyj aspekty (Freedom of conscience in Russia: historical and modern aspects), 2. Retrieved from https://rusoir.ru/03print/ 03print-04/03print-04-02/ (In Russian).

Leo XIII (1891). Rerum Novarum. Libreria Editrice Vaticana: the Holy See. Retrieved from http://w2.vatican.va/content/leo-xiii/ en/encyclicals/documents/hf_I-xiii_enc_15051891_rerumnovarum.pdf.

Ratnikov, A. (2014). Word and Deal: How did the Pope influence politics? RBC. December 18. Retrieved from https:// www.rbc.ru/photoreport/18/12/2014/5492de2a9a79476a065c08c3 (In Russian).

Sardarian, H. T. (2016). The liberal reversal of Catholic social doctrine during the pontificate of Leo XIII. Pravo i polytyka (Law and politics), 11: 1433-1439. DOI: https://doi.org/10.7256/18119018.2016.11.20685 (In Russian).

Sardarian, H. T. (2017). Political Doctrine of Pope John XXIII. Polytyka i Obshchestvo (Politics and Society), 11: 155-162. DOI: https://doi.org/10.7256/2454-0684.2017.11.24672 (In Russian).

Yarotskyi, P. (2001). Features of the development of social teaching of Catholicism. Ukrainske relihiieznavstvo (Ukrainian Religious Studies), 20, 55-63 (In Ukrainian).

Yevdokymova, T. (2000). Christian Social Teaching: Dialogue with the Modern World. Ukrainske relihiieznavstvo (Ukrainian Religious Studies), 15: 13-22 (In Ukrainian).

\section{LIST OF REFERENCE LINKS}

Аронов Е., Гостев А. Большая политика папы. Радио Свобода: веб-сайm. URL: https://www.svoboda.org/a/27261162.html (Дата обращения: 29.12.2019).

Голубев К., диак. Позиционирование католического социального учения в энцикликах папы римского Ивана Павла II. Христианское чтение. 2012. № 6. С. 95-130. 
Євдокимова Т. Християнське соціальне вчення: діалог з сучасним світом. Українське релігієзнавство. 2000. № 15. C. 13-22.

Каневский К. Социальная доктрина Католической церкви. Российская юстиция. 2003. № 4. URL: https://www.sovacenter.ru/religion/publications/2003/12/d1475/?print=1 (Дата обращения 27.05.2019).

Компендіум Соціальної доктрини Церкви. Київ: Кайрос, 2008. 549 с.

Кондрусевич Т., митрополит. Церковь и государство в Учении католической церкви. Свобода совести в России: исторический и современный аспекты. 2005. Выпуск № 2. URL: https://rusoir.ru/03print/03print-04/03print-04-02/ (Дата обращения: 16.09.2019)

Ратников А. Слово и дело: как папы римские влияли на политику? РБК: веб-сайт. 18.12.2014. URL: https://www.rbc.ru/ photoreport/18/12/2014/5492de2a9a79476a065c08c3 (Дата обращения: 15.10.2019).
Сардарян Г. Т. Либеральный разворот католического социального учения в период понтификата Льва XIII. Право и политика. 2016. № 11. C. 1433-1439. DOI: https://doi.org/10.7256/ 1811-9018.2016.11.20685

Сардарян Г. Т. Политическая доктрина Папы Иоанна XXIII. Политика и Общество. 2017. № 11. C. 155-162. DOI: https:// doi.org/10.7256/2454-0684.2017.11.24672.

Филиппов Б. Кардинал Стефан Вышиньский - инициатор и критик "восточной политики" Ватикана. Государство, религия, церковь в России и за рубежом. 2017. № 1. С. 98-122. DOI: https://doi.org/10.22394/2073-7203-2017-35-1-98-122.

Четверикова О. Н. Измена в Ватикане, или Заговор пап против христианства. Москва: Эксмо, 2011. 240 с.

Яроцький П. Особливості розвитку соціального вчення католицизму. Українське релігієзнавство. 2001. № 20. С. 55-63.

Leo XIII. Rerum Novarum (15.05.1891). Libreria Editrice Vaticana: the Holy See. URL: http://w2.vatican.va/content/leo-xiii/ en/encyclicals/documents/hf_I-xiii_enc_15051891_rerum-novarum.pdf (Retrieved from 03.05.2019).

Дмитро Гончаренко,

Київький університет імені Бориса Грінченка (м. Київ, Украӥна)

e-mail: d.goncharenko86@gmail.com,ORCID 0000-0002-2597-9740

\section{ЧИ МІСТИТЬ СОЦІАЛЬНЕ УЧЕННЯ КАТОЛИЦЬКОЇ ЦЕРКВИ ОСУЧАСНЕНІ ЕЛЕМЕНТИ CEPEДHЬOBIYHOÏ DOCTRINA DE DUO GLADI?}

Метою середньовічного католицького політико-теологічного учення про "два мечі" було обґрунтування тези щодо верховенства влади пап Римських над політичною владою, що давало можливість духовному інституту претендувати на справи світського і державного порядку. Проте внаслідок реформаторських процесів у Європі, учення про "два мечі" було нівельоване, але є припущення, що окремі елементи доктрини могли зберегтися до нашого часу й використовуватись Церквою у адоптованому відповідно до вимог часу вигляді. Розв'язання поставленої проблеми спирається на дослідження соціальних доктрин Римо-Католицької Церкви, оскільки саме католицьке соціальне учення увібрало в себе цілу низку питань світської спрямованості, що дає можливість Церкві впливати на громадянське суспільство, порушуючи проблеми в економічній, політичній та соціальній царині. Враховуючи, що учення про "два мечі" містило політичну складову, основний акцент статті робиться на вивченні теоретичних і практичних кроків Римо-Католицької Церкви на дипломатичній та геополітичній арені, що в певному сенсі можуть відповідати положенням середньовічної доктрини. Утім, приділяючи увагу соціально-політичним аспектам, Церква залишає за собою право здійснювати морально-етичний контроль як за суспільством так і за владою й тим самим демонструвати, що на духовний інститут покладається важлива роль у формуванні архітектури сучасного світу. Отже, основним результатом статті є дослідження католицького соціального учення та його політичної складової, зокрема, виявлення елементів, які можна інтерпретувати як сучасну реалізацію середньовічної теорії "двох мечів".

Ключові слова. Католицька Церква; доктрина; "два мечі"; дипломатія; католицьке соціальне учення; понтифрік; геополітика; держава; політика.

(C) Dmytro Honcharenko

Надійшла до редакції: 04.01.2020

Прийнята до друку: 23.01.2020 